\title{
THE IMPORTANCE OF DETERMINING SARS-COV-2 N-Ag SERODIAGNOSTICS FOR THE MANAGEMENT OF COVID-19 PNEUMONIA IN HOSPITAL SETTINGS
}

Lebedin YuS ${ }^{1}$, Lyang $\mathrm{OV}^{2}$, Galstyan $\mathrm{AG}^{2}$, Panteleeva $\mathrm{AV}^{1}$, Belousov $\mathrm{W}^{2,3}$, Rebrikov DV ${ }^{3}$

${ }^{1}$ XEMA Co. Ltd., Moscow, Russia

${ }^{2}$ Federal Center of Brain Research and Neurotechnologies of the Federal Medical Biological Agency, Moscow, Russia

${ }^{3}$ Center for Precision Genome Editing and Genetic Technologies for Biomedicine, Pirogov Russian National Research Medical University, Moscow, Russia

A new coronavirus infection caused by the SARS-CoV-2 virus, which appeared in December 2019, has claimed the lives of 2.5 million people in almost a year. The high contagiousness of this virus has led to its wide and rapid spread around the world. As of February 2021, the total number of cases is 111 million people; more than 4 million cases of SARS-CoV-2 infection have been registered in the Russian Federation. To successfully combat the emerging pandemic, it is necessary to quickly diagnose the disease at an early stage, which will prevent the further spread of this virus and prescribe the necessary treatment on time. The aim of the work was to evaluate the use of the SARS-CoV-2 nucleocapsid antigen (N-Ag) and respective antibodies as diagnostic markers in pneumonia patients. The study was conducted at the height of COVID-19 pandemic in Moscow, Russia. It included 425 emergency patients with clinical signs of COVID-19 pneumonia, of which 280 (66\%) were positive for either serum N-Ag and/or its respective antibodies. We demonstrate the total prevalence of N-Ag seroconversion in SARS-CoV-2associated pneumonia patients within 3-5 days after hospital admission. The results indicate high feasibility of SARS-CoV-2 serodiagnostics in emergency patients.

Keywords: SARS-CoV-2, COVID-19, nucleocapsid antigen, seroconversion

Funding: this work was partially supported by a grant № 075-15-2019-1789 from the Ministry of Science and Higher Education of the Russian Federation allocated to the Center for Precision Genome Editing and Genetic Technologies for Biomedicine.

Acknowledgement: we acknowledge Natalia Usman for helpful discussions

Author contribution: Lebedin YS designed the study, performed the sampling, conducted molecular studies and drafted the manuscript, Lyang OV and Galstyan AG performed the clinical examinations and sampling, conducted biochemical and molecular studies, Panteleeva AV conducted molecular studies and drafted the manuscript, Belousov W and Rebrikov DV designed the study and drafted the manuscript. All authors read and approved the final version of the manuscript.

Compliance with ethical standards: the study protocol was reviewed and approved by the Local Ethics Committee at the Pirogov Russian State Medical University (Protocol № 2020/07 dated March 16, 2020,); the study was conducted in accordance with the Declaration of Helsinki.

$\triangle$ Correspondence should be addressed: Yuri S. Lebedin

9-ya Parkovaya, 48, Moscow, 105264; lebedin@xema-medica.com

Preprint published: 25.09.2020 DOI: 10.1101/2020.09.24.20200303

Received: 11.02.2021 Accepted: 24.02.2021 Published online: 28.02.2021

DOI: $10.24075 /$ brsmu.2021.009

\section{ВАЖНОСТЬ ОПРЕДЕЛЕНИЯ N-АНТИГЕНА ВИРУСА SARS-COV-2 ДЛЯ ЛЕЧЕНИЯ ПНЕВМОНИИ COVID-19 В УСЛОВИЯХ СТАЦИОНАРА}

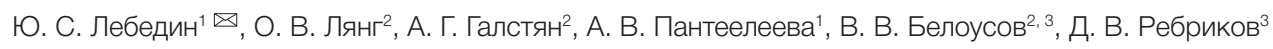

1 OОО «ХЕМА», Москва, Россия

2 Федеральный центр мозга и нейротехнологий Федерального медико-биологического агентства, Москва, Россия

${ }^{3}$ Центр высокоточного редактирования и генетических технологий для биомедицины, Российский национальный исследовательский медицинский университет имени Н. И. Пирогова, Москва, Россия

Появившаяся в декабре 2019 г. новая коронавирусная инфекция, вызванная вирусом SARS-CoV-2, почти за год унесла жизни 2,5 млн человек. Высокая контагиозность вируса привела к его широкому и быстрому распространению по всему миру. По состоянию на февраль 2021 г. общее число заболевших достигает 111 млн человек; в РФ зарегистрировано более 4 млн случаев заражения SARS-CoV-2. Для успешной борьбы с возникшей пандемией необходимо быстро диагностировать заболевание на ранней стадии, что позволит предотвращать дальнейшее распространение этого вируса и своевременно назначать необходимое лечение. Целью работы было оценить использование нуклеокапсидного антигена (N-Ag) SARS-CoV-2 и соответствующих антител в качестве диагностических маркеров у больных пневмонией. Исследование проводили в разгар пандемии COVID-19 в Москве (Россия). В него вошли 425 экстренных пациентов с клиническими признаками пневмонии COVID-19, из которых 280 (66\%) были положительны либо на сывороточный N-Ag, либо на соответствующие ему антитела. Продемонстрирована общая распространенность сероконверсии N-Ag у пациентов с пневмонией, ассоциированной с SARS-CoV-2, в течение 3-5 дней после госпитализации. Полученные результаты свидетельствуют о высокой целесообразности серодиагностики SARS-CoV-2 у экстренных больных.

Ключевые слова: SARS-CoV-2, COVID-19, нуклеокапсидный антиген, сероконверсия

Финансирование: работа выполнена при частичной поддержке гранта Министерства науки и высшего образования Российской Федерации № 075-152019-1789, выделенного Центру высокоточного редактирования и генетических технологий для биомедицины.

Благодарности: мы благодарим Наталью Усман за помощь в обсуждении

Вклад авторов: Ю. С. Лебедин - разработка концепции, отбор проб, молекулярные исследования, редактирование рукописи; О. В. Лянг, А. Г. Галстян - клинические обследования, отбор проб, биохимические и молекулярные исследования; А. В. Пантелеева - молекулярные исследования; редактирование рукописи, В. В. Белоусов, Д. В. Ребриков - подготовка исследования; редактирование рукописи. Все авторы прочли и одобрили окончательный вариант рукописи.

Соблюдение этических стандартов: исследование одобрено этическим комитетом РНИМУ им. Н. И. Пирогова (протокол № 2020/07 от 16 марта 2020 г.), проведено в соответствии с требованиями Хельсинкской декларации.

$\bowtie$ Для корреспонденции: Юрий Степанович Лебедин 9-я Парковая, д. 48, 105264, г. Москва; lebedin@xema-medica.com

Препринт опубликован: 25.09.2020 DOI: 10.1101/2020.09.24.20200303

Статья получена: 11.02.2021 Статья принята к печати: 24.02.2021 Опубликована онлайн: 28.02.2021

DOI: $10.24075 /$ vrgmu.2021.009 
Immunochemical detection of antigens in blood is widely used in the diagnostics of infectious diseases. The antigenemia tests are usually targeted at blood-borne pathogens (notably chronic viral infections including cytomegalovirus, hepatitis B and C viruses, and HIV [1-3]). In respiratory diseases, the penetration of the pathogen components (nucleic acids or proteins) into non-respiratory body fluids is likely, but their detection is usually considered of minor value because of the focal nature of the pathogenesis and its strong association with mucous immunity. Despite that, certain respiratory infections can be efficiently diagnosed and monitored by detection of corresponding antigens in the blood; the examples include galactomannan in pulmonary aspergillosis [4] and L. pneumophila antigen in urine of Legionnaires' disease patients [5]. In addition, the use of serological immunoassays for the management of virusassociated nosocomial pneumonias in intensive care unit patients has been reported $[4,6]$. Serum nucleocapsid antigen $(\mathrm{N}-\mathrm{Ag})$ of SARS virus was described in SARS-associated pneumonia by Che et al $[7,8]$.

The aim of the work was to evaluate the use of the SARSCoV-2 nucleocapsid antigen (N-Ag) and respective antibodies as diagnostic markers and demonstrate the total prevalence of $\mathrm{N}$-Ag seroconversion in SARS-CoV-2-associated pneumonia patients.

\section{METHODS}

The study was carried out at the Federal Center of Brain Research and Neurotechnologies during the spring of 2020. At the height of the COVID-19 pandemic, the in-patient care facilities of the Center were redesigned for the emergency hospitalization and management of the SARS-CoV-2associated pneumonia patients. The study involved patients with clinical signs of COVID-19 pneumonia $(n=425)$ flown by ambulance services from different districts of Moscow. Inclusion criteria: presence of clinical signs of COVID-19 pneumonia (fever with a combination of two or more clinical signs, including body temperature $\geq 38.5^{\circ} \mathrm{C}$, respiratory rate $\geq 30$ breaths per minute, and/or $\mathrm{SpO}_{2} \leq 93 \%$ ) [9]. Serum samples for the study were collected from each patient at least twice; sampling at the admission and at the discharge was carried out concomitantly with the mandatory procedure for routine blood tests. The in-patient care lasted $20 \pm 2$ days. Criteria for the discharge included a reduction in C-reactive protein levels at WBC counts within the normal range (above $4.0 \times 10^{9} \mathrm{~L}$ ) and, notably, a clear tendency towards regression of characteristic signs revealed by computer tomography: the absence of new ground glass opacities, a decrease in the severity of the corresponding changes in the lung tissue and/or a decrease in the volume or degree of consolidation of the ground glass opacities (no more than three, each within $3 \mathrm{~cm}$ along the maximal dimension) [10]. The qualitative RT-PCR detection of SARS-CoV-2 RNA in nasopharyngeal swabs was carried out at the admission with the use of SARS-CoV-2/SARS-CoV Multiplex Real-Time PCR Detection Kit (DNA-Technology LLC; Russia); analytical sensitivity is 10 copies per amplification tube, diagnostic sensitivity - 100\% (95\% Cl: 95.6-100\%), diagnostic specificity $100 \%$ (95\% Cl: $96.7-100 \%)$ according to the manufacturer's protocol.

\section{SARS-Cov-2 nucleocapsid antigen ( $\mathrm{N}-\mathrm{Ag}$ ) coding sequence}

SARS-Cov-2 nucleocapsid antigen ( $\mathrm{N}-\mathrm{Ag}$ ) coding sequence (NCBI accession number 045512.2) was cloned by Ndel/Xhol into pET-30b(+) vector, Novagen (EMD Millipore; USA); the plasmid was expanded in E. coli Top10 and transformed into E. coli Rosetta (DE3) for N-Ag expression.

The conditions were optimized for $37{ }^{\circ} \mathrm{C}$ bioreactor fermentation in $3000 \mathrm{~mL}$ of rich media (yeast extract, bacto peptone, glucose and trace salts). After $12 \mathrm{~h}$ incubation, the culture was induced with $2.5 \mathrm{mM}$ imidazole for $4 \mathrm{~h}$. The obtained biomass was resuspended in phosphate buffered saline (PBS) in $1: 3(\mathrm{w} / \mathrm{v})$ proportion and disrupted using APV-2000 homogenizer (Spx Flow; USA) at 1200 bar. The solution was clarified by centrifugation at 12,000 $\mathrm{g}$. The insoluble fraction (inclusion bodies) containing the target protein was washed sequentially with PBS, $2 \%$ Triton in PBS and a fresh portion of PBS to remove the residual detergent. The protein was dissolved in $8 \mathrm{M}$ urea with $250 \mathrm{mM} \mathrm{NaCl}$ and $50 \mathrm{mM}$ phosphate, $\mathrm{pH}$ 10.0. The solution was incubated at $+4{ }^{\circ} \mathrm{C}$ overnight and centrifuged at $15,000 \mathrm{~g}$; the collected supernatant was filtered and supplemented with $20 \mathrm{mM}$ imidazole to prevent the non-specific binding of impurities. The polyhistidine-tagged N-Ag protein was purified by immobilized metal affinity chromatography using a nickel column High Density Nickel \#6BCL-QHNi (ABT; Spain) equilibrated with the urea buffer. The protein was eluted with $250 \mathrm{mM}$ imidazole buffer and filter-sterilized through filters with a diameter of $0.45 \mu \mathrm{m}$.

\section{Serum IgG antibodies against nucleocapsid antigen (N-IgG)}

Serum IgG antibodies against nucleocapsid antigen (N-lgG) were detected by solid-phase enzyme immunoassay. Briefly, the recombinant full-length SARS-CoV-2 nucleocapsid antigen produced in E. coli (XEMA; Russia) was coated onto the surface of polystyrene microwells. The sera pre-diluted 100fold in the ELISA buffer $(0.1 \%$ Tween-20 and $1 \%$ hydrolyzed casein in $0.1 \mathrm{M} \mathrm{PBS}$ ) were placed in the microwells for 30 min at $37{ }^{\circ} \mathrm{C}$. After 3 washes with $0.1 \%$ Tween-20 in 0.9\% sodium chloride, the wells were exposed to the conjugate of murine monoclonal antibodies XG78 against human IgG (gamma chain) with horseradish peroxidase (XEMA; Russia) for 30 min. After 5 washes with $0.1 \%$ Tween-20 in $0.9 \%$ sodium chloride, the bound enzyme was revealed by addition of the substrate-chromogenic mix (TMB substrate, XEMA; Russia). The color development was stopped by $5 \%$ sulfuric acid and the optical density (OD) at $450 \mathrm{~nm}$ was measured in a plate reader Multiskan MC (Thermo Labsystems; Finland). The internal controls (stabilized human serum containing specific IgG antibodies) were included in all microplates to calculate the positivity threshold OD for each run individually. The results are expressed as positivity indexes (calculated as OD for a sample of interest related to OD for the internal control).

\section{Serum IgM antibodies against nucleocapsid antigen (N-IgM)}

Serum IgM antibodies against nucleocapsid antigen (N-lgM) were detected by reverse solid phase enzyme immunoassay. Briefly, murine monoclonal antibody against the mu chain of human IgM (clone X616, XEMA; Russia) was adsorbed on the surface of polystyrene microwells. The dilutions of sera (prepared in the same way as for the IgG assay) were placed in the microwells for 30 min at $37^{\circ} \mathrm{C}$. After 3 washes with $0.1 \%$ Tween-20 in $0.9 \%$ sodium chloride, a working dilution of the recombinant full-length SARS-CoV-2 nucleocapsid antigen conjugated with horseradish peroxidase in the ELISA buffer was placed in the microwells for 30 min at $37^{\circ} \mathrm{C}$. After 


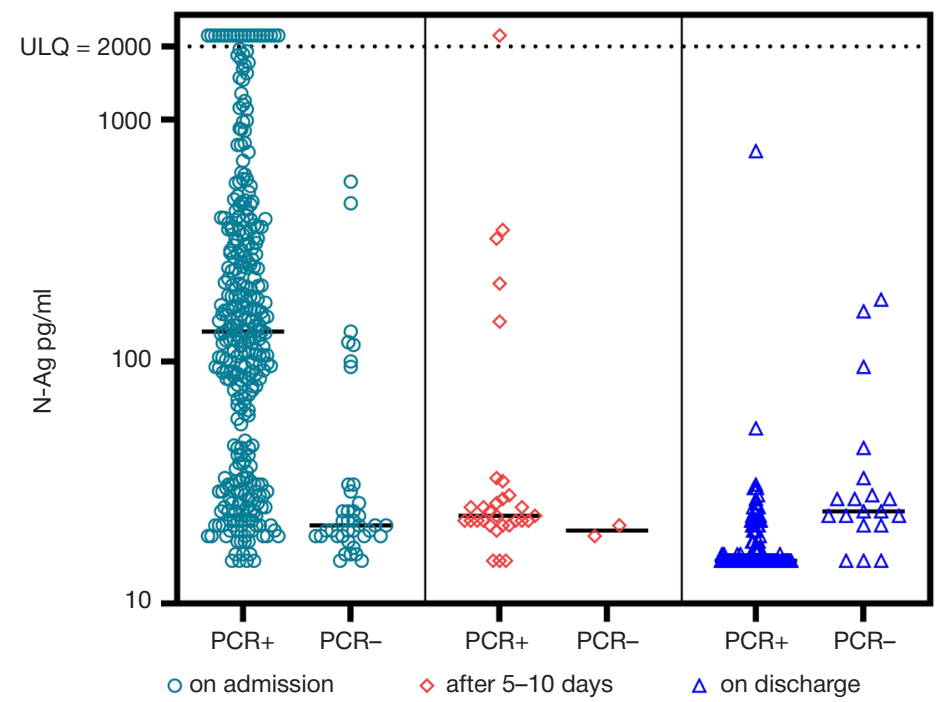

Fig. 1. Dynamics of serum N-Ag levels in the studied cohort of hospital patients. ULQ, upper limit of quantification. The 'PCR+' and 'PCR-' indications refer to the patient's status on admission

5 washes with $0.1 \%$ Tween-20 in $0.9 \%$ sodium chloride, the bound labeled antigen was detected by TMB substrate and $O D$ reading. The calculation of positivity index (similarly with the IgG assay) was performed by using the internal lgM+ control.

\section{Serum $\mathrm{N}$-antigen $(\mathrm{N}-\mathrm{Ag})$ determination}

Serum N-antigen (N-Ag) determination was performed by the two-site solid-phase sandwich method using monoclonal antibodies (mAbs) generously gifted by Hytest Ltd (Turku; Finland). The microwells were coated with the capture mAb NP1510. Serum samples or assay calibrators (solutions of nucleocapsid antigen in donor serum in the range 20-2000 $\mathrm{pg} / \mathrm{ml}$ ) were incubated with a working dilution of HRP-labeled tracer monoclonal antibody (clone NP1517) in ELISA buffer with the addition of heterophilic immunoglobulin elimination reagent $\left(10 \mu \mathrm{g} / \mathrm{ml}\right.$, HIER-E-010, Fapon Biotech; China) for $2 \mathrm{~h}$ at $37^{\circ} \mathrm{C}$ under continuous 600 rpm shaking in a PST-60HL-4 shaking incubator (Biosan; Latvia). The detection was performed with the use of TMB substrate (XEMA; Russia) and OD reading. The N-Ag concentrations were determined by calibration curve method using. $\mathrm{N}$-Ag concentrations exceeding the upper limit of calibration curve $(2000 \mathrm{pg} / \mathrm{ml})$ were shown as $2222 \mathrm{pg} / \mathrm{ml}$ in calculations and graphic presentation. The samples with OD readings corresponding to concentrations lower than $20 \mathrm{pg} / \mathrm{ml}$,

\section{A}

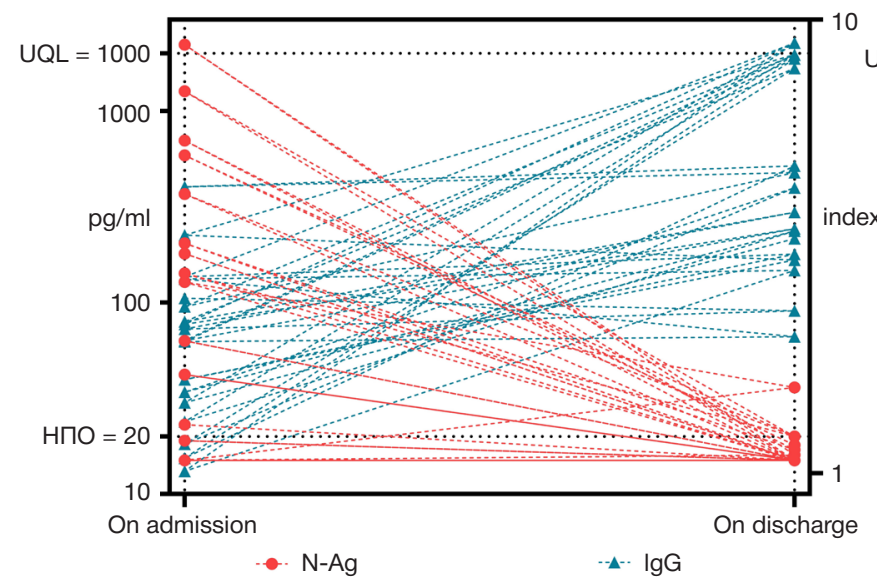

lacking resolution from the zero calibrator, were conventionally assigned $15 \mathrm{pg} / \mathrm{ml}$ values in the presented data.

\section{Statistical processing}

The data were processed in GraphPad Prism 8.0 (GraphPad Software, Inc.; USA) and Microsoft Excel 2016 (Microsoft; USA).

The reference ranges were determined by analysis of serum samples collected from healthy donors $(n=250)$ before Dec 2019. In both assays, the threshold (cutoff) values were set to attain full specificity (none of the donors being considered positive).

\section{RESULTS}

The immunoassay-based detection of serum $\mathrm{N}-\mathrm{Ag}$ in combination with its respective antibodies confirmed COVID-19 in 280 patients $(66 \%)$ of the studied cohort. RT-PCR analysis of nasopharyngeal swabs confirmed COVID-19 in 76\% of the patients; the interception constitutes 63\% and corresponds to the concordance of $79 \%$.

Several patients $(n=21 ; 5 \%)$ were identified as SARSCoV-2 negative by both RT-PCR tests and serodiagnostics, and most likely represented cases on non-SARS-CoV-2associated pneumonias. The small number of such patients is

\section{B}

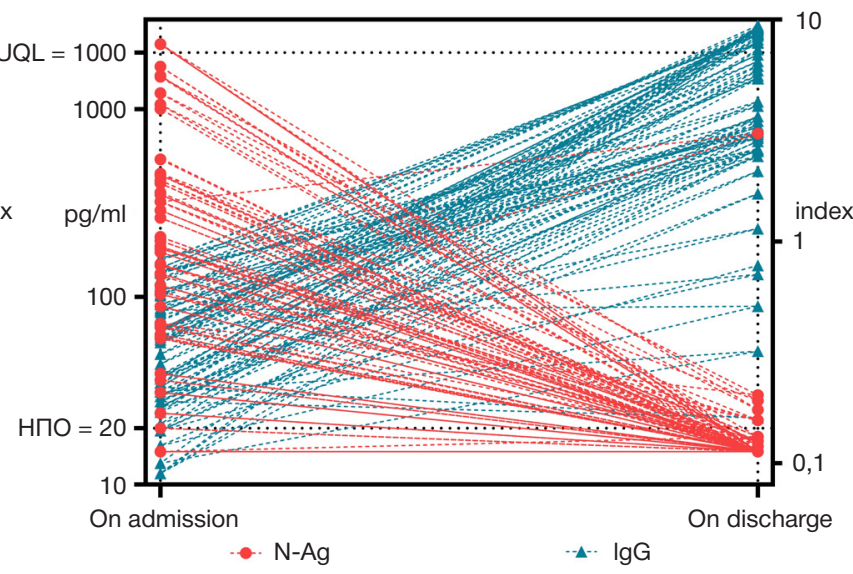

Fig. 2. Dynamics of serum N-Ag levels vs. respective lgG antibodies in patients lgG-seropositive on admission (A) and patients lgG-seronegative on admission (B). Vertical axes correspond to Ag concentration (on the left) and Ab index (on the right). ULQ, upper limit of quantification; LOD, (lower) limit of detection 
A

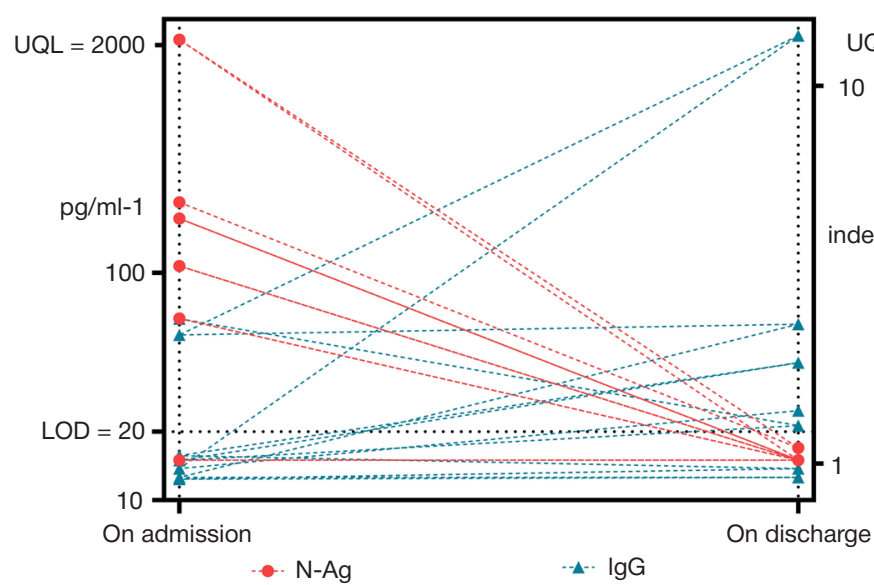

B

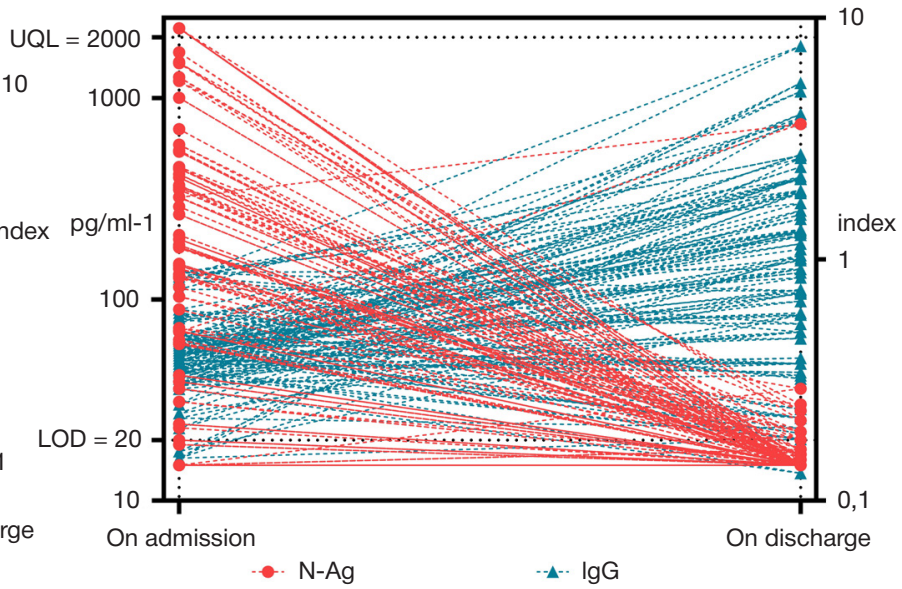

Fig. 3. Dynamics of serum N-Ag levels vs. respective lgM antibodies in patients IgM-seropositive on admission (A) and patients IgM-seronegative on admission (B). Vertical axes correspond to Ag concentration (on the left) and Ab index (on the right). ULQ, upper limit of quantification; LOD, (lower) limit of detection

explained by the fact that the study was carried out at the peak of the pandemic.

According to the data, $\mathrm{N}$-Ag antigenemia is characteristic of the majority of patients with severe COVID-19 (63\%).

The disease phase-related dynamics of serum N-Ag levels are shown in Fig 1. At the discharge, most of the patients $\mathrm{N}$-Ag positive at the admission (104 of 116; 90\%) showed serum N-Ag levels below the lower limit of the calibration curve (<20 pg/ml; 104 of 116; 90\%). However, some patients were clearly positive for serum $\mathrm{N}$-Ag even at the discharge.

By the time of discharge, seroconversion was observed in most of the patients $\mathrm{N}-\mathrm{Ag}$ positive at the admission (108 of $116 ; 93 \%)$, although the degree of seroconversion varied considerably.

\section{DISCUSSION}

To determine seroconversion patterns, we plotted serum N-Ag levels with two isotypes of antibody response for individual cases, dividing them in two subgroups by Ab-seropositivity on admission (Fig. 2A and 3A vs. 2B and 3B). The results indicate reciprocal patterns for $\mathrm{N}-\mathrm{Ag}$ and respective antibodies, which is characteristic of classical seroconversion. The patients Ab-seronegative on admission (presumably being at the earlier stage of the disease) showed more distinct patterns of classical seroconversion. The lgG-antibody patterns were more pronounced than the IgM-antibody patterns in both groups.

Co-detection of $\mathrm{N}-\mathrm{Ag}$ and anti-N-Ag antibodies in 92 (18\%) of 503 serum samples demonstrates that the epitope recognized by immunoassay pair used for the antigen determination is at least not fully overlapped (masked) by the human antibody response.

For a subcohort of 20 patients, we had the opportunity to evaluate seroconversion within a shorter period of several days. According to the results shown in Figure 4, in the majority of cases the switch from $\mathrm{Ag}+\mathrm{Ab}$ - to $\mathrm{Ag}-\mathrm{Ab}+$ status proceeded within 3-5 days after the emergency admission.

According to the results of the study, hospitalization of the patients with SARS-CoV-2-associated pneumonia at the height of pandemic most frequently occurred before the onset of seroconversion (i.e. against the background of detectable serum $\mathrm{N}$-Ag concentrations). In the majority of patients the antigen prevailed at the time of admission and was "replaced" with respective antibodies by the time of discharge. Nevertheless, in some cases, by the time of emergency hospitalization, the level of antibodies to N-Ag in the patient's blood was already high, probably reflecting either delayed hospitalization or individual variation in the COVID-19 pathogenesis.

Overall, the obtained results indicate high feasibility of SARSCoV-2 serodiagnostics in the emergency patients (along the

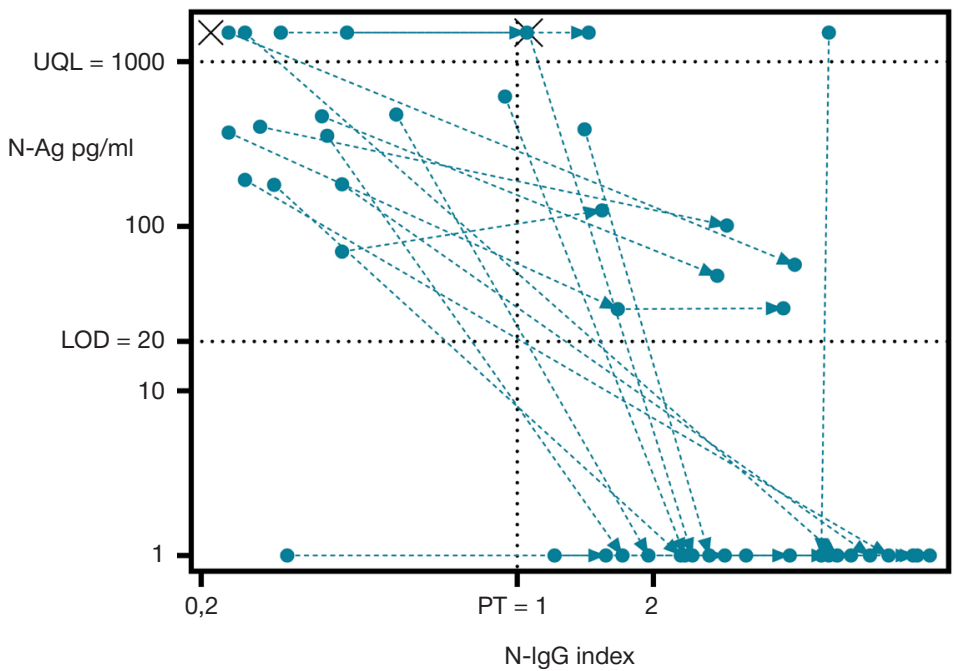

Fig. 4. Individual patterns of seroconversion in the course of 3-5 days after the admission. ULQ, upper limit of quantification; LOD, (lower) limit of detection; PT, positivity threshold 
lines of 'rapid tests' Capillus HIV-1/HIV-2 ${ }^{\circledR}$, Determine HIV-1/2 ${ }^{\circledR}$, etc. currently proposed as a gold standard of HIV diagnostics instead of the more expensive and time-consuming western blot analysis [11]). Similar conclusions were drawn in the study of small groups of patients with confirmed SARS-CoV-2 using various methods of immunochemical analysis [12, 13].

It should be noted that false-positive results of SARSCoV-2 serodiagnostics may appear in patients with high levels of rheumatoid factor or HAMA antibodies, which underscores the significance of personalized comprehensive diagnostics for the patients with severe COVID-19.

\section{CONCLUSION}

Overall, the results indicate high relevance of combined serological tests for SARS-CoV-2 N-Ag and the antibodies to SARS-CoV-2 antigens as applied to the infectious pneumonia emergency patients at the admission, since 1) sensitivity and specificity of the serological test for $\mathrm{N}$-Ag is comparable to that of the RT-PCR analysis of nasopharyngeal swabs, and the use of serology tests in combination with PCR tests for SARSCoV-2 provides a significant increase in the overall sensitivity; 2) processing of blood samples is safer for the personnel due to the negligible presence of SARS-CoV-2 infectious particles in the blood, by contrast with nasopharyngeal swabs; 3) serological tests are generally faster than RT-PCR tests (when accounting for the full cycle of biomaterial processing and sample preparation), which accelerates the determination of SARS-CoV-2 status for a prompt decision on the management mode and isolation measures; in addition, blood serum analyses are easier to automate; 4) collection of blood samples for serodiagnostics of SARS-CoV-2 in hospital settings is not an additional invasive procedure, but is performed as a part of the mandatory primary examination immediately upon the admission (as well as of the final examination upon the discharge from the hospital).

\section{References}

1. Dioverti MV, Razonable RR. Cytomegalovirus. Microbiol Spectr. 2016; 4 (4). DOI: 10.1128/microbiolspec.DMIH2-0022-2015.

2. Laing N, Tufton H, Ochola E, P'Kingston OG, Maini MK, Easom N. Hepatitis B assessment without hepatitis B virus DNA quantification: a prospective cohort study in Uganda. Trans R Soc Trop Med Hyg. 2019; 113 (1): 11-17. DOI: 10.1093/trstmh/try117.

3. Thai KTD, Götz H, Slingerland BCGC, Klaasse J, Schutten M, GeurtsvanKessel $\mathrm{CH}$. An analysis of the predictive value of the HIV $\mathrm{Ag} / \mathrm{Ab}$ screening assay within the performance characteristics of the DiaSorin LIAISON XL for the detection of blood-borne viruses. $J$ Clin Virol. 2018; 102: 95-100. DOI: 10.1016/j.jcv.2018.02.018.

4. Loughlin L, Hellyer TP, White PL, et al. Pulmonary Aspergillosis in Patients with Suspected Ventilator-associated Pneumonia in UK Intensive Care Units [published online ahead of print, 2020 Jul 1]. Am J Respir Crit Care Med. 2020; 10.1164/rccm.2020020355OC. DOI: 10.1164/rccm.202002-0355OC.

5. Edelstein PH, Jørgensen CS, Wolf LA. Performance of the ImmuView and BinaxNOW assays for the detection of urine and cerebrospinal fluid Streptococcus pneumoniae and Legionella pneumophila serogroup 1 antigen in patients with Legionnaires' disease or pneumococcal pneumonia and meningitis. PLoS One. 2020; 15 (8): e0238479. Published 2020 Aug 31. DOI: 10.1371/ journal.pone.0238479.

6. Chiche L, Forel JM, Papazian L. The role of viruses in nosocomial pneumonia. Curr Opin Infect Dis. 2011; 24 (2): 152-56. DOl: 10.1097/QCO.0b013e328343b6e4.

7. Che XY, Qiu LW, Pan YX, Wen K, Hao W, Zhang LY, et al. Sensitive and specific monoclonal antibody-based capture enzyme immunoassay for detection of nucleocapsid antigen in sera from patients with severe acute respiratory syndrome. J Clin Microbiol. 2004 Jun; 42 (6): 2629-35. DOI: 10.1128/JCM.42.6.2629-2635.2004.

8. Xiao-yan Che, Biao Di, Guo-ping Zhao, Ya-di Wang, Li-wen Qiu, Wei Hao, et al. A Patient with Asymptomatic Severe Acute

\section{Литература}

1. Dioverti MV, Razonable RR. Cytomegalovirus. Microbiol Spectr. 2016; 4 (4). DOI: 10.1128/microbiolspec.DMIH2-0022-2015.

2. Laing $N$, Tufton $H$, Ochola E, P'Kingston OG, Maini MK, Easom N. Hepatitis B assessment without hepatitis B virus DNA quantification: a prospective cohort study in Uganda. Trans R Soc Trop Med Hyg. 2019; 113 (1): 11-17. DOl: 10.1093/trstmh/try117.

3. Thai KTD, Götz H, Slingerland BCGC, Klaasse J, Schutten M, GeurtsvanKessel $\mathrm{CH}$. An analysis of the predictive value of the HIV $\mathrm{Ag} / \mathrm{Ab}$ screening assay within the performance characteristics of

the DiaSorin LIAISON XL for the detection of blood-borne viruses. J Clin Virol. 2018; 102: 95-100. DOI: 10.1016/j.jcv.2018.02.018.

4. Loughlin L, Hellyer TP, White PL, et al. Pulmonary Aspergillosis in Patients with Suspected Ventilator-associated Pneumonia in UK Intensive Care Units [published online ahead of print, 2020 Jul 1]. Am J Respir Crit Care Med. 2020; 10.1164/rccm.2020020355OC. DOI: 10.1164/rccm.202002-0355OC.

5. Edelstein PH, Jørgensen CS, Wolf LA. Performance of the ImmuView and BinaxNOW assays for the detection of urine and 
cerebrospinal fluid Streptococcus pneumoniae and Legionella pneumophila serogroup 1 antigen in patients with Legionnaires' disease or pneumococcal pneumonia and meningitis. PLoS One. 2020; 15 (8): e0238479. Published 2020 Aug 31. DOI: 10.1371/ journal.pone.0238479.

6. Chiche L, Forel JM, Papazian L. The role of viruses in nosocomial pneumonia. Curr Opin Infect Dis. 2011; 24 (2): 152-56. DOI: 10.1097/QCO.0b013e328343b6e4.

7. Che XY, Qiu LW, Pan YX, Wen K, Hao W, Zhang LY, et al. Sensitive and specific monoclonal antibody-based capture enzyme immunoassay for detection of nucleocapsid antigen in sera from patients with severe acute respiratory syndrome. J Clin Microbiol. 2004 Jun; 42 (6): 2629-35. DOI: 10.1128/JCM.42.6.26292635.2004.

8. Xiao-yan Che, Biao Di, Guo-ping Zhao, Ya-di Wang, Li-wen Qiu, Wei Hao, et al. A Patient with Asymptomatic Severe Acute Respiratory Syndrome (SARS) and Antigenemia from the 20032004 Community Outbreak of SARS in Guangzhou, China, Clinical Infectious Diseases. 2006; 43 (1): e1-e5. DOI: 10.1086/504943.

9. Приказ департамента здравоохранения города Москвы от 22 марта 2020 г. № 230 «Об утверждении регламентов (алгоритмов) работы медицинских организаций, подведомственных Департаменту здравоохранения города Москвы в период с 23 по 30 марта 2020 г. по оказанию медицинской помощи пациентам, заболевшим новой коронавирусной инсекцией (COVID-19), и контактным с ними лицам». Доступно по ссылке: https://rg.ru/2020/03/24/ moscow-prikaz230-reg-dok.html.

10. Приказ Департамента здравоохранения города Москвы от 06 апреля 2020 г. № 351 «О порядке выписки из медицинских организаций (стационаров), подведомственных Департаменту здравоохранения города Москвы, пациентов с внебольничной пневмонией или коронавирусной инфекцией (COVID-19), для продолжения лечения в амбулаторных условиях (на дому)». Доступно по ссылке: https://www.mos.ru/ dzdrav/documents/department-acts/view/239550220/.

11. Huang X, Liu X, Chen J, et al. Evaluation of Blood-Based Antibody Rapid Testing for HIV Early Therapy: A Meta-Analysis of the Evidence. Front Immunol. 2018; 9: 1458. Published 2018 Jun 26. DOI: 10.3389/fimmu.2018.01458.

12. Le Hingrat Q, Visseaux B, Laouenan C, Tubiana S, Bouadma L, Yazdanpanah $Y$, et al. Detection of SARS-CoV-2 N-antigen in blood during acute COVID-19 provides a sensitive new marker and new testing alternatives. Clinical Microbiology and Infection. December 2020. DOI: 10.1016/j.cmi.2020.11.025.

13. Ogata AF, Maley AM, Wu C, Gilboa T, Norman M, Lazarovits R, et al. Ultra-Sensitive Serial Profiling of SARS-CoV-2 Antigens and Antibodies in Plasma to Understand Disease Progression in COVID-19 Patients with Severe Disease, Clinical Chemistry. 2020; 66 (12): 1562-72. DOI: 10.1093/clinchem/hvaa213. 